\title{
EFEKTIVITAS PENGGUNAAN VIDEO BASED LEARNING PADA PEMBELAJARAN JARAK JAUH PENDIDIKAN ANAK USIA DINI
}

\author{
Budi Setiawan ${ }^{1}$, Shiffa Intan Amarthani', Syifa Nabila Akhyar ${ }^{3}$ \\ Universitas Pendidikan Indonesia \\ 'ubdi_setiawan@upi.edu, ${ }^{2}$ shiffa.intan@upi.edu, ${ }^{3}$ syifanabila52@upi.edu
}

\begin{abstract}
Abstrak: Pembelajaran jarak jauh (PJJ) merupakan salah satu kebijakan pemerintah untuk memutuskan mata rantai penyebaran virus covid-19 yang diterapkan pada seluruh jenjang pendidikan. Kegiatan PJJ ini mengakibatkan, dibutuhkannya bantuan dari teknologi dan media dalam penyampain materi pembelajaran, khususnya pada jenjang PAUD yang proses pembelajarannya sangat membutuhkan bimbingan secara intensif dari pendidik. Video based learning merupakan media yag dapat dipilih oleh pendidik sebagai alternatif PJJ pada jenjang PAUD. Tujuan dari penelitian ini adalah untuk mengidentifikasi dan mendapatkan informasi terkait efektivitas penggunaan video based learning sebagai media pembelajaran pada anak usia dini di masa pembelajaran jarak jauh. Penelitian menggunakan metode studi kasus eksplorasi dan pendekatan penelitiannya menggunakan metode studi kasus kualitatif. Hasil penelitian menunjukkan bahwa penggunaan video based learning dinilai efektif sebagai salah satu alteratif media pembelajaran jarak jauh bagi anak usia dini, karena dapat meningkatkan motivasi dan pemahaman peserta didik terkait materi yang disampaikan.
\end{abstract}

Kata Kunci: anak usia dini , efektivitas, pembelajaran berbasis video, pembelajaran jarak jauh

\begin{abstract}
Distance learning is one of the government's policies to break the chain of covid-19 virus which is applied to all levels of education. Distance learning activity involve technology and media for delivering learning materials, especially at the preschool where the learning process really needed intensive guidance from educators. Video based learning is a medium that can be chosen by educators as an alternative to distance learning at the preschool. The purpose of this study was to identify and obtain information related to the effectiveness of using video-based learning as a learning medium for preschool in distance learning. The research uses an exploratory case study method and the research approach uses a qualitative case study method. The results showed that the use of video based learning was considered effective as an alternative media for distance learning for preschool, because it could increase students' motivation and understanding regarding the material presented.
\end{abstract}

Keywords: preschool, effectiveness, video based learning, distance education

\section{PENDAHULUAN}

Sejak ditetapkannya Covid Virus Diseases (Covid-19) sebagai pandemi yang melanada lebih dari 200 negara di dunia, termasuk Indonesia oleh organisasi kesehatan dunia (WHO). Pemerintah Indonesai akhirnya menegeluarkan kebijakan untuk menutup seluruh fasilitas umum. Pemerintah mengharuskan segala aktivitas masyarakat baik pekerjaan maupun pendidikan dilakukan di rumah guna mencegah rantai penyebaran virus Covid-19. Dalam bidang pendidikan kondisi ini memberikan dampak secara langsung terhadap pelaksanaan pembelajaran. Banyak lembaga pendidikan baik informal, nonformal, dan formal menutup seluruh akses kegiatan pembelajaran secara langsung dan beralih pada pembelajaran jarak jauh.

Dengan peralihan pembelajaran yang terbilang cukup cepat yang disebabkan oleh pandemi memiliki dampak tersendiri, baik pada pendidik, orang tua peserta didik, maupun pada diri peserta didik tersebut. Dampak yang terasa antara lain, para peserta didik merasa dipaksa belajar jarak jauh tanpa sarana dan prasarana yang memadai sehingga terdapat beberapa peserta didik kesulitan untuk menyimak proses pembelajaran secara online, terlebih lagi di Negara kita yang belum memiliki pengalaman dalam kegiatan pembelajaran jarak jauh, tentunya memerlukan waktu yang cukup panjang untuk beradaptasi. Selain itu, dampak sekolah yang diliburkan terlalu lama membuat peserta didik merasa jenih dan kehilangan jiwa sosialnya karena mereka tidak banyak berinteraksi dengan temannya secara langung.

Kemudian, baik pendidik, orang tua peserta didik dan peserta didik dituntut untuk memiliki kecapakan dalam hal pengoperasian teknologi (Purwanto, dkk., 2020, hal. 5-7). 
Setiap pendidik dijenjang yang berbeda tentu harus memiliki suatu kecakapan khusus, tak terkecuali pada pendidik dalam jenjang pendidikan anak usia dini. Berikut merupakan kecakapan yang dinilai harus dimiliki oleh guru PAUD (Hendy: 2020)

1. Guru harus cepat beradaptasi dengan teknologi informasi, karena pembelajaran

2. Jarak jauh yang perlu didukung oleh perangkat teknologi.

3. Guru PAUD juga dituntut kreatif dan inovatif. Seperti menggunakan sampah untuk kerajinan tangan yang dapat diterapkan peserta didik dan orangtuanya di rumah.

4. Guru PAUD harus memiliki kemampuan komunikasi yang baik dengan orangtua murid. Peran orangtua murid sangat dibutuhkan sebagai penghubung antar peserta didik dan pendidik dalam membantu kelancaran proses belajar-mengajar.

Adapun dampak lain ialah terdapat penurunan capaian belajar disebabkan karena adanya perbedaan akses dan kualitas saat proses pembelajaran, baik kualitas jaringan internet ataupun perangkat yang digunakan (Wijaya, L, D., \& Kurniawati, E., 2020). Pembelajaran jarak jauh ini memberikan banyak sekali pro dan kontra dari masyarakat Indonesia, karena tak banyak yang berpendapat juga bahwa pembelajaran jarak jauh membuat anak menjadi kurang memhami akan materi yang sedang dipelajari.

Pandemi ini sungguh berdampak besar pada pendidikan terutama pada pendidikan anak usia dini. Mengingat pembelajaran untuk anak usia dini yang sangat berbeda dengan jenjang lainnya. Kemampuan siswa pada jenjang ini masih sulit untuk menerima informasi yang komplek, pemecahan masalah dan pemakaian alat (Astini,2020). Pendidikan anak usia dini atau dikenal dengan PAUD adalah salah satu pembinaan yang ditujukan kepada anak didik sejak lahir hingga menginjak usia enam tahun, yang dilakukan melalui pemberian rangsangan pendidikan untuk membantu pertumbuhan dan perkembangan jasmani serta rohani anak guna memiliki kesiapan dalam memasuki pendidikan lebih lanjut (Kemendikbud RI Dirjen PAUD, 2016).

Pendidikan anak usia dini memiliki karakteristik yang unik mengikuti tahapan usianya, sehingga dibutuhkan upaya untuk pengembangan aspek perkembangannya dengan kegiatan belajar sambil bermain. Anak usia dini merupakan anak yang berada dalam proses pertumbuhan dan perkembangan dalam membentuk karakter dan kepribadian anak yang memiliki karakteristik pertumbuhan dan perkembangan fisik, motorik, kognitif atau intelektual (daya pikir, daya cipta), sosial emosional, serta bahasa (Margiani, V., 2014, hal. 11). Dapat kita simpulkan dari beberapa penegrtian diatas bahwa, pendidikan anak usia dini sangatlah penting bagi anak sebelum menginjak pada masa Pendidikan Sekolah Dasar.

Adanya Pendidikan anak usia dini bertujuan untuk mempersiapkan anak mencapai kedewasaannya serta mengembangkan potesnipotensi yang dimiliki dan diminati oleh anak, baik yang sudah ada dalam dirinya maupun yang belum terdapat dalam diri anak. Dalam hal ini anak usia dini masih membutuhkan dorongan serta bimbingan yang baik dari pendidik karena sejatinya anak usia dini masih belum mengetahui apa-apa kecuali tentang dirinya, keluarganya serta hal-hal kecil yang terjadi disekitarnya.

Mengingat hal tersebut, pendidik perlu memiliki inovasi dalam proses pelaksanaan pembelajaran yang mana saat ini diselenggarakan secara jarak jauh atau online. Salah satu inovasi yang dapat pendidik terapkan pada pembelajaran jarak jauh yaitu penggunaan media pembelajaran yang mampu menyampaikan pembelajaran kepada peserta didik secara menarik, efektif dan menyenangkan. Media pembelajaran merupakan sebuah alat bantu untuk menyalurkan materi atau bahan pembelajaran dari pendidik terhadap peserta didik, yang mana dengan penggunaan media pembelajaran ini dapat merangsang pikiran serta perasaan peserta didik dalam kegiatan pembelajaran.

"Media" berasal dari kata latin yang merupakan bentuk jamak dari kata "medium". Secara harfiah kata tersebut mempunyai arti perantara atau pengantar. Ada banyak pakar yang mendefinisikan media, berikut beberapa diantaranya:

1. Media merupakan teknologi pembawa pesan yang dapat dimanfaatkan untuk keperluan pembelajaran. Jadi media adalah perluasan guru (Schram, 1982)

2. National Education Asociation (NEA) memberikan batasan bahwa media merupakan sarana komunikasi dalam bentuk cetak maupun audio visual, termasuk teknologi perangkat kerasnya. 
3. Briggs berpendapat bahwa media merupakan alat untuk memberikan perangsanng bagi siswa supaya terjadi proses belajar

4. Asociation of Education Communication Technology (AECT) memberikan batasan bahwa media merupakan segala bentuk dan saluran yang dipergunakan untuk proses penyaluran pesan

5. Sedangkan Gagne berpendapat bahwa berbagai jenis komponen dalam lingkungan siswa yang dapat merangsang siswa untuk belajar

6. Segala sesuatu yang dapat digunakan untu menyalurkan pesan yang dapat merangsang pikiran, perasaan, dan kemauan siswa untuk belajar (Miarso, 1989)

Media pembelajaran terdiri atas dua unsur penting, yaitu unsur perlatan atau perangkat keras (hardware) dan unsur pesan yang dibawanya (massage/ software). Pada proses pembelajaran jarak jauh tentunya membutuhkan media pembelajaran yang efektif dan efisen sebagai perantara anatra pendidik dan peserta didik. Saat ini banyak sekali media pembelajaran yang ditawarkan, dari media audio, visual, teks, dan audio-visual yang dapat membantu pendidik dalam proses pembelajaran. Salah satu media yang dapat digunakan untuk menunjang pembelajaran jarak jauh ialah video based learning. Video based learning merupakan salah satu trend teknologi pendidikan pada era revolusi 4.0 yang mana konsep dari media ini memanfaatkan sedikitnya dua elemen yaitu visual dan audio dalam menyampaikan suatu bahan ajar kepada para peserta didik.

Menurut Nugent (dalam Smaldino, S,E., dkk., 2011:404), banyak guru menggunakan video untuk memperkenalkan sebuah topik baru, menyajikan konten pembelajaran, menyediakan perbaikan pembelajaran, dan meningkatkan pengayaan pada diri peserta didiknya. Setiap segmen video dapat digunakan diseluruh lingkungan pengajaran baik di dalam kelas, kelompok kecil, dan siswa-siswa perorangan (Smaldino, S,E., dkk., 2011:404). Terdapat beberapa macam video based learning yang di kelompokkan ke dalam beberapa jenis media. Djarmah dan Aswan (dalam Putry, M, E, H., dkk., 2020 hal.14) mengelompokkan media video based learning berdasarkan keberadaannya yaitu menjadi dua macam, yaitu: Media video based learning gerak dan media video based learning diam. Media video based learning gerak merupakan salah satu media yang menampilkan dua unsur yang dapat bergerak yaitu unsur suara dan unsur gambar. Contohnya seperti; 1) Televisi yang merupakan salah satu sistem elektronik yang mampu menampilkan gambar dan suara secara bersamaan dengan perantara kabel atau ruangan; 2) Video yang merupakan salah satu bagian dari media audio visual yang bergerak dengan menampilkan gambar beserta suara dalam keadaan bergerak; dan 3) Film bersuara yang merupakan gabungan dari beberapa gambar dalam frame yang kemudian dapat diproyeksikan dengan menghubungkan lensa proyektor atau LCD dengan listrik secara mekanis sehingga dapat dilihat pada layar berupa gambar dan disertai suara. Sedangkan, media video based learning diam biasanya dinamakan dengan film bingkai suara (sound slide) yang mana merupakan salah satu dari media video dengan menampilkan unsur suara dan gambar diam. Sound slide merupakan slide yang ditambah dengan suara dari sumber audio yang berbeda, bukan alat audio visual lengkap.

Keuntungan yang akan didapatkan saat menggunakan video dalam pembelajaran, diantaranya: mampu meningkatkan kemampuan motorik peserta didik, tingkat keefektifan video sangatlah baik karena dapat diputar kapan saja dan dimana saja sesuai dengan situasi dan kondisi, memungkinkan para peserta didik untuk mengamati fenomena yang mungkin saja terlalu berbahaya untu dilihat secara langsung, membentuk sikap personal dan sosial, dan dapat membangun dasar kesamaan pengalaman untuk membahas sebuah isu secara efektif.

Latar belakang dari penulisan artikel ini diantaranya untuk mencari tahu tentang; Bagaimana pelaksanaan pembelajaran jarak jauh Pendidikan Anak Usia Dini. Metode dan media apa saja yang digunakan oleh pendidik saat pembelajaran jarak jauh pada Pendidikan Anak Usia Dini. Apakah media pembelajaran seperti video based learning sering diterapkan pada Pendidikan Anak Usia Dini. Apakah terdapat pengaruh secara signifikan setelah dan sebelum menggunakan video based learning pada pembelajaran? Apa saja kendala yang dialami saat menggunakan media video based leraning Penelitian ini bertujuan untuk mendapatkan informasi mengenai efektivitas penggunaan video based learning pada pembelajaran jarak jauh pendidikan anak usia dini. 


\section{METODE PENELITIAN}

Penelitian ini menggunakan metode studi kasus eksploratif dengan pendekatan penelitian kualitatif yang digunakan untuk mendapatkan informasi mengenai efektivitas penggunaan video learning pada pembelajaran jarak jauh pendidikan anak usia dini. Banyak sample didasarkan pada pencapaian kedalam dan kekayaan deskripsi, bukan banyak sample yang didapatkan. Menurut Guetterman (dalam Rosyada, 2020:154) pada prinsipnya, pertimbangan pengambilan sampel bukan keterwakilan seluruh anggota populasi, tapi kekayaan informasi. Marshall (dalam Rosyada, 2020:154) juga berpendapat bahwa besar kecilnya sampel kualitatif ditentukan oleh kompleksitas masalah yang diangkat, karena semakin kompleks masalah penelitian maka akan semakin besar ukuran sampelnya dan semakin sederhana masalahnya maka akan semakin kecil juga sampel yang dibutuhkan oleh peneliti. Responden untuk penelitian ini adalah para guru dan wali murid.

Terdapat dua data yang penulis kumpulkan, yaitu data primer dan data sekunder. Data primer dikumpulkan dengan wawancara, sedangkan data sekunder dikumpulkan dari berbagai jurnal dan buku yang relevan dengan kasus yang penulis angkat. Penelitian ini terbatas pada ukuran sampe 5 responden dari kelas yang sama. Sampel dipilih dengan metode purposive sampling. Dalam penelitian kualitatf, teknik purposive sampling merupakan metode yang digunakan untuk mencapai tujuan penelitian tertentu. Dalam teknik purposive sampling tidak ada batas jumlah responden untuk membuat sample purposive, asalkan informasi yang diinginkan dapat diperoleh (Bernard, 2002).

Dalam menjalankan penelitian studi kaus kami juga mengimbangi dengan wawancara untuk mendapatkan hasil yang maksimal. Wawancara dilakuakan di kelas yang sama dan menggunakan daftar pertanyaan yang telah disusun sebelumnya yang kemudian dari daftar pertanyaan ini dapat dikembangkan berdasarkan literatur terkait.

\section{HASIL DAN PEMBAHASAN}

Pandemi Covid-19 memberikan pengaruh besar bagi berbagai sektor yang ada di Indonesia, salah satunya sektor pendidikan. Dampak dari covid-19 mengharuskan seluruh jenjang pendidikan melaksanakan pembelajaran dari rumah masing-masing peserta didik atau biasa dikenal dengan istilah pembelajaran jarak jauh (PJJ). Hal ini sesuai dengan Surat Edaran Menteri Pendidikan dan Kebudayaan Republik Indonesia Nomor 4 Tahun 2020 tentang Pelaksanaan Kebijakan Pendidikan dalam Masa Darurat Penyebaran Corona Disease (Covid-19). Salah satu isi kebijakan tersebut adalah pelaksanaan proses pembelajaran yang diadakan dari rumah masing-masing menggunakan strategi pembelajaran jarak jauh. PJJ dilakukan dengan tujuan untuk mengurangi resiko penyebaran virus Corona. Kementerian Pendidikan dan Kebudayaan Republik Indonesia (2020) menyampaikan bahwa tujuan dari pemberlakuan pembelajaran Jarak jauh adalah :

1. Memastikan pemenuhan hak peserta didik untuk mendapatkan pelayanan pendidikan selama covid-19,

2. Melindungi masyarakat Indonesia terutama satuan pendidikan terhadapdampak buruk dari covid-19

3. Mencegah terjadinya penyebaran dan penularan covid-19 di satuan pendidikan,

4. Memastikan memberikan dukungan psikososial bagi pendidik, peserta didik dan orangtua/wali

Pembelajaran jarak jauh (PJJ) merupakan pola pembelajaran yang berlangsung antara peserta didik dan pendidik yang berlangsung di tempat yang terpisah. Menurut UU Nomor 20 Tahun 2003 pasal 1 Ayat 15 pendidikan jarak jauh merupakan pendidikan yang anak didiknya terpisah dari pendidik dan pembelajarannya menggunakan berbagai sumber belajar melalui teknologi dan komunikasi dan media lain. Pendidikan jarak jauh juga dikenal dengan istilah E-learning. E-learning merupakan aplikasi yang menghubungkan pendidik dan peserta didik yang keterbatasan ruang dan waktu agar pembelajaran dapat berlangsung. (Kusuma, 2011).

Pembelajaran jarak jauh (PJJ) sejatinya bukan strategi pembelajaran baru dalam sistem pendidikan. Strategi pembelajaran ini telah digunakan di Amerika Serikat sekitar tahun 1892 yang diluncurkan pertama kali oleh Universitas Chicago untuk tingkat perguruan tinggi. Di Indonesia sendiri strategi Pembelajaran Jarak Jauh belum banyak digunakan diberbagai jenjang pendidikan. Namun, setelah maraknya penyebaran virus covid-19 di Indonesia, akhirnya Indonesia pun mencoba menerapkan strategi Pembelajaran Jarak jauh ini (PJJ).

Berdasarkan surat edaran keluaran Kementrian Pendidikan dan Kebudayaan No. 4 Tahun 2020 tentang pelaksanaan 
pendidikan. Dalam Masa Darurat Corona Virus Disease (Covid-19) terdapat poin-poin pelaksanaan Pembelajaran Jarak jauh (PJJ) sebagai berikut: (1) Belajar dilakukan di rumah melalui kegiatan daring atau jarak jauh tanpa membebani siswa dengan tuntutan capaian kurikulum; (2) Pembelajaran dari rumah difokuskan pada kecakapan hidup; (3) Materi dapat dikondisikan sesuai minat dan kondisi masing- masing siswa termasuk mempertimbangkan fasilitas yang dimiliki siswa; dan (4) Penilaian merupakan umpan balik yang bersifat kualitatif.

Namun, pada pelaksanannya tetap saja penerapan pembelajaran jarak jauh ini memberikan tantangan tersendiri bagi para pelaku pendidikan khususnya di Negara Indonesia, karena para pendidik dituntut untuk mampu menyampaikan ilmu pengetahuan terhadap peserta didik tanpa melakukan tatap muka. Sesuai dengan surat edaran yang dikeluarkan oleh Mentri Pendidikan dan Kebudayaan Republik Indonesia Nomor 4 Tahun 2020 tentang Pelaksanaan Kebijakan Pendidikan dalam Masa Darurat Penyebaran Corona Virus Diseas (Covid-19). Atsani, 2020 menyatakan bahwa penggunaan Whatsapp Group pada pembelajaran jarak jauh merupakan aplikasi yang mudah dan fleksibel sebagai penghubung antara pendidik, peserta didik, dan orangtua. Menurut penelitian, Fitur Whatsapp Group yang beragam seperti pesan suara, pesan teks, panggilan video, terima kirim gambar, video dan dokumen file memudahkan pendidik dalam proses pembelajaranjarak jauh. Kegiatan yang diberikan lebih kepada pengembangan keterampilan hidup dan karakter anak yang dusesuaikan dengan tema yang berurut.

Pembelajaran jarak jauh merupakan sistem pembelajaran yang berlangsung tanpa tatap muka secara langsung antara pendidik dan peserta didik.

Dalam pembelajaran jarak jauh pendidik dapat mengkolaborasikan tiga pendekatan, diantaranya:

1. Synchronous: Interaksi pembelajaran antara pendidikan dengan peserta didik yang dilakukan pada waktu bersamaan dengan menggunakan teknologi. Contohnya meliputi presentasi dalam ruangan, siaran televisi langsung (bukan rekaman video), atau telekonferensi.

2. Asynchronous: Interaksi pembelajaran antara pendidik dan peserta didik yang tidak dalam waktu bersamaan dimana pendidik harus menyiapkan terlebih dahulu materi kemudian interaksi pembelajarannya dilakukan secara fleksibel dan tidak harus dalam waktu yang sama. Contoh menggunakan forum diskusi atau belajar mandiri seperti penugasan kepada peserta didik, belajar melalui buku, atau juga dapat belajar melalui rekaman video yang telah dibuat oleh pendidik.

3. Jadwal Terbuka: Hampir serupa dengan pembelajaran asinkron, dengan pembatasan yang lebih sedikit sehingga memungkinkan siswa melakukan berbgaui kegiatan dengan perencanaannya sendiri

Selain ketiga pendekatan tersebut pendidik juga perlu memilih beberapa metode guna menunjang terselengaranya pendidikan jarak jauh dengan maksimal. Dalam penggunaan metode, pendidik dapat menggunakan lebih dari satu metode atau dikenal dengan multi metode untuk mencapai hasil pembelajaran yang memuaskan. Menurut (Srigati, 2015, hal. 156) penggunaan multi metode dalam pembelajaran memiliki keunggulan, diantaranya; (1) Dapat menyajikan pembelajaran yang aktif, kreatif, efektif, menarik, dan menyenangkan; (2) memiliki daya serap yang tinggi, sehingga siswa memasuki daya ingat yang cukup lama; (3) kegiatan banyak berpusat kepada siswa (student centre) sehingga pendidik hanya sebagai fasilitator saja; dan (4) dapat memperlihatkan moralitas belajar siswa baik auditorial, visual, dan kinestetik.

Penggunaan multi metode pada pembelajaran jarak jauh pendidikan anak usia dini perlu memperhatikan situasi belajar agar sesuai dengan kebutuhan pengajaran para peserta didik. Dalam hal ini yang harus diperhatikan yaitu materi pembelajaran yang akan disampaikan kepada peserta didik. Di mana pendidik perlu memutuskan kapan yang paling efektif bagi para peserta didik untuk berada dalam situasi aktual bersama dengan pendidik dan kapan peserta didik bisa bekerja secara mandiri. Selain untuk meningkatkan hasil pembelajaran, penggunaan multi metode pada pembelajaran jarak jauh untuk pendidikan anak usia dini dinilia penting agar peserta didik tidak bosan dengan situasi belajar yang sedang ia hadapi. Dari hasil wawancara yang telah dilaksanakan, penulis mendapatkan informasi bahwa dibeberapa PAUD yang penulis kunjungi telah menggunakan multi metode untuk menunjang pembelajaran jarak jauh. Metode 
yang digunakan yaitu metode penugasan dan metode diskusi.

Menurut Slameto dalam (Darmadi, 2017, hal. 194) Metode penugasan atau resitasi merupakan metode penyampaian bahan pelajaran dengan memberikan tugas kepada peserta didik untuk dikerjakan dalam rentangan dan hasilnya harus dipertangungjawabkan kepada pendidik. pemberian tugas ini dapat berupa tugas yang bersifat individual maupun berkelompok dengan tujuan untuk merangsang agar peserta didik aktif belajar. Menurut (Aidid, 2020, hal. 7) metode penugasan ini memiliki kelebihan diantaranya; (1) lebih merangsang siswa dalam melakukan aktivitas belajar individual ataupun kelompok; (2) dapat mengembangkan kemandirian siswa di luar pengawasan guru, (3) dapat meminta tanggung jawab dan disiplin siswa, serta (4) dapat mengembangkan kreativitas siswa.

Menurut purwanto, dkk dalam (Sudiyono, 2020, hal. 11) metode diskusi dapat didefinisikan sebagai bentuk tukar pikiran yang dilakukan oleh dua orang atau lebih untuk menghasilkan kesepakatan atau keputusan bersama. Metode ini dapat digunakan dalam tahap pengajaran dan pembelajaran apapun dan dalam kelompok kecil ataupun kelompok besar. Metode diskusi ini merupakan cara untuk menakar pengetahuan, keterampilan, dan sikap dari sekelompok siswa. Metode diskusi bisa dipimpin oleh pendidik dengan mengajukan pertanyaan untuk mendapatkan respon dari peserta didik.

Baik metode penugasan dan metode diskusi dianggap sangat efektif untuk pembelajaran jarak jauh di masa pandemi Covid-19 ini. Karena metode ini merupakan metode yang paling mudah untuk diterapkan selama peserta didik belajar dari rumah. Baik metode penugasan ataupun metode diskusi sangat cocok diaplikasikan untuk semua kalangan siswa. Dengan dipadukannya kedua metode ini pendidik dapat memilih kapan saatnya pendidik memberikan tugas kepada peserta didik dan kapan pendidik bertatap muka untuk menyampaikan materi pembelajaran yang baru dan menanyakan hasil perkembangan penugasan yang telah diberikan.

Selain harus memilih metode pembelajaran yang tepat, strategi pembelajaran jarak jauh juga mengakibatkan, dibutuhkannya bantuan dari teknologi dan media dalam penyampain materi pembelajaran. Pembelajaran jarak jauh dapat melibatkan berbagai teknologi dan media termasuk pada pemanfaatan video dan program komputer yang dapat dikirimkan kepada peserta didik perorangan.Terdapat berbagai jenis media yang dapat digunakan oleh pendidik dalam menunjang pembelajaran, berdasarkan presepsi indra manusia, media dapat dikelompokkan menjadi tiga, yaitu media audio, media visual, dan media audio visual (Pakpahan, dkk., 2020, hal63 ).

Media audio merupakan media yang menggunakan indra pendengaran sebagai perantara dalam menyampaikan isi media atau mengandalkan suara saja dalam penggunaannya. Menurut rusman media audio mengandung pesan auditif sehingga dapat merangsang pikiran, perasaan, perhatian, kreativitas, dan inovatif peserta didik. Media audio menuntut kemampuan daya dengar dan menyimak dari peserta didik, sehingga media audio sangat cocok digunakan untuk siswa yang cenderung lebih senang mendengarkan materi pembelajaran. Media yang termasuk dalam media audio antara lain adalah radio, rekaman suara, piringan hitam, dll.

Media visual merupakan media yang menggunakan indra penglihatan sebagai perantara dalam penyampaian isi media. Media visual terbagi menjadi dua, yaitu media dua dimensi dan media tiga dimensi. Media visual dua dimensi merupakan media yang hanya memiliki ukuran dimensi yaitu panjang dan lebar saja atau media yang dapat dilihat dalam bidang datar. Salah satu contoh media visual dua dimensi adalah media grafis. Media grafis merupakan media yang berasal dari kumpulan titik, garis, tulisan, gambar dan visual lainnya. Media grafis merupakan media yang umum digunakan dalam pembelajaran karena pembuatannya yang sangat mudah dan efisien. Selain media dua dimensi terdapat juga media tiga dimensi. Media tiga dimensi merupakan media yang menyajikan tidak hanya dapat dilihat namun juga dapat disentuh dan dirasakan secara nyata. Media tiga dimensi ini bisa berbentuk makhluk hidup maupun benda mati. Contohnya seperti globe, hewan, tumbuhan, manusia, maket, dll.

Media audio visual merupakan media yang memanfaatkan indra pendengaran dan penglihatan secara bersamaan. Contoh dari media audio visual yaitu berupa video, film, televisi, dll. Menurut (Pakpahan, et al., 2020, hal. 66) media audio visual terbagi menjadi dua yaitu audio visual murni dan audio visual tidak murni. Audio visual murni adalah audio media yang baik unsur gambar maupun suaranya berasal dari suatu 
sumber misalnya video dokumenter, sedangkan audio visual tidak murni unsur gambar dan suara pada media tersebut tidak berasal dari satu sumber. Misalnya slide presentasi yang diberi rekaman suara tambahan (Haryoko dalam (Pakpahan, dkk., 2020, hal. 66).

Menurut Rahardjo (Ana Widyastuti, dkk., 2020, hal. 54) Media dapat dibedakan menjadi dua macam menurut kriteria aksesibilitasnya, yaitu media by Utilization (media yang dimanfaatkan), dan media by design (media yang dirancang). Media by Utilization atau media yang dimanfaatkan merupakan media yang biasanya dibuat untuk kepentingan komersial yang terdapat di berbagai laman. Dalam hal ini, pendidik dapat langsung memanfaatkannya sesuai dengan kebutuhan yang diperlukan. Pendidik tidak perlu merancang dari awal hingga akhir sendiri. Namun, pendidik harus mengeluarkan sejumlah biaya untuk dapat memanfaatkannya. Sedangkan media by design merupakan media yang dirancang di mana harus dikembangkan sendiri oleh pendidik. Dalam hal ini, pendidik dituntut untuk mampu merancang dan mengembangkan sendiri media tersebut sesuai dengan kebutuhan yang diperlukan oleh pendidik dengan memanfaatkan sarana dan kelengkapan yang dimilikinya.

Menurut (Rusman, 2018:222) Pemilihan media pembelajaran harus dilakukan secara sistematis berfokus pada pembentukan kompetensi siswa. Di mana dalam pengembangannya harus tergambarkan dalam pengembangan kegiatan pembelajaran. Terdapat beberapa tahap yang harus diperhatikan dalam pemilihan media pembelajaran, diantaranya :

a. Menentukan media pembelajaranberdasarkan identifikasi tujuan pembelajaran atau kompetensi dan karakteristik aspek materi pembelajaran yang akan dipelajari.

b. Mengidentifikasi karakteristik media pembelajaran harus disesuaikan dengan tingkat kemampuan siswa, penggunaannya dikuasai oleh pendidik, sudah tersedia di sekolah, mudah dalam penggunaannya, tidak memerlukan waktu yang banyak atau sesuai dengan waktu yang disediakan, dapat mencapai tujuan pembelajaran dan meningkatkan kreativitas dari peserta didik.

c. Mendesain penggunaannya dalam proses pembelajaran bagaimana tahap penggunaannya sehingga menjadi proses yang utuh dalam proses pembelajaran tersebut. d. Mengevaluasi penggunaan media pembelajaran sebagai bahan umpan balik dari efektivitas dan efisiensi media pembelajaran tersebut.

Hasil dari penelitian yang telah penulis lakukan memungkinkan bahwa video based learning merupakan salah satu media pembelajaran alternatif yang dapat digunakan oleh para tenaga pendidik diberbagai jenjang, termasuk pada jenjang pendidikan usia dini. Penggunaan video based learning dapat dijadikan sebgai salah satu media selingan disamping penugasan tema, home visit dan juga pertemuan melaui telekonferensi.

Video merupakan jenis media audio visual yang pemakaiannya mengandalkan dua indera manusia, yaitu pendengaran dan penglihatan. Menurut Mahadewi (2012:4) media video pembelajaran dapat diartikan sebagai media yang digunakan untuk merangsang pikiran, perasaan dan kemauan siswa untuk belajar melalui penayangan ide atau gagasan, pesan dan informasi secara audio visual. Video pembelajaran yang dirancang secara menarik dapat merangsang minat anak. Minat adalah kesadaran sesorang, bahwa suatu objek, seseorang, suatu soal atau situasi mengandung sangkut paut dengan dirinya (M. Buchori, 1999: 135) Minat inilah yang penting dalam proses belajar, karena dengan minat seseorang akan melakukan sesuatu hal dengan sungguh-sunnguh sesuai dengan apa yang orang itu minati, karena adanya minat dalam diri seseorang akan menimbul motivasi belajar Berdasarkan hasil penelitian psikologi menunjukkan bahwa kurangnya minat pada suatu bidang tertentu akan mempengaruhi hasil akhir dari proses pembelajaran (Slameto, 2010) dapat disimpulkan bahwa minat belajar dinilai sangat penting, karena lebih jauh lagi, akan berdampak pada hasil belajar

Efektivitas media video dilandasi oleh teori dari Edgar dale yang menggambarkan tingkatan pemahaman siswa dalam sebuah kerucut pengalaman. Teori tersebut menegaskan bahwa siswa akan semakin merasakan pengalaman pembelajaran apabila siswa menggunakan lebih banyak panca inderanya. Gambaran visual dapat mengkomunikasikan pesan dengan cepat dan nyata, oleh karena itu dapat mempercepat pemahaman pesan secara lebih komprehensif. Pesan visual lebih efektif dan efisien dalam arti penyajian visual dapat membuat anak didik lebih berkonsentrasi. 
Media pembelajaran video dapat dilakukan dalam pembelajaran jarak jauh karena dapat dilakukan secara online tanpa harus adanya tatap muka di kelas. Sebelum pembelajaran dimulai, pendidik terlebih dahulu membuat materi dan mengemasnya dalam bentuk video. Menurut penilitian, Pembelajaran video dinilai efektif dalam pembelajaran karena dapat meningkatkan minat siswa dalam belajar karena bentuk pengemasannya yang menarik. Video pembelajaran juga dapat memberikan pengalaman belajar yang sama seperti di kelas walau hanya dari satu arah, berdasarkan faktor tersebut, siswa menjadi lebih gampang memahami konsep pembelajaran. Penggunaan video pada pembelajaran usia dini sangat disarankan, akan tetapi akan lebih baik apabila diselingi dengan metode pembelajaran lainnya untuk menjaga proses pembelajaran yang dinamis dan mencegah kejenuhan pada anak.

Proses

belajar menggunakanvideopembalajaran ada baiknya apabila dapat terus dipantau oleh orangtua murid agar pembelajaran berjalan kondusif dan terbimbing. Peran orangtua sangat dibutuhkan dalam pembelajaran jarak jauh, Menurut Winingsih (2020) terdapat empat peran orang tua selama. Pembelajaran Jarak Jauh (PJJ) yaitu:

a. Orang tua memiliki peran sebagai guru di rumah, yang di mana orang tua dapat membimbing anaknya dalam belajar secara jarak jauh dari rumah.

b. Orang tua sebagai fasilitator, yaitu orang tua sebagai sarana dan pra-sarana bagi anaknya dalam melaksanakan pembelajaran jarak jauh.

c. Orang tua sebagai motivator, yaitu orang tua dapat memberikan semangat serta dukungan kepada anaknya dalam melaksanakan pembelajaran, sehingga anak memiliki semangat untuk belajar, serta memperoleh prestasi yang baik.

d. Orang tua sebagai pengaruh atau director.

Walupun sekilas memiliki banyak keuntungan, metode pembelajaran video tidak dapat menggantikan pembelajaran tatap langsung, menurut penelitian, orangtua menilai bahwa anak lebih baik belajar langsung di sekolah karena dapat berinteraksi langung dengan guru juga dapa bersosialisasi dengan teman temannya. Pembelajaran di rumah juga dinilai tidak efektif karena tidak semua orangtua dapat terus terusan mendampingi anaknya dalam belajar.

\section{PENUTUP}

Pembelajaran jarak jauh merupakan sistem pembelajaran yang berlangsung tanpa tatap muka secara langsung antara pendidik dan peserta didik. Dalam hal ini tentu pembelajaran jarak jauh memerlukan media dan teknologi sebagai penunjangnya. Namun, selain media dan teknologi yang dibutuhkan guna menunjang pembelajaran jarak jauh yaitu perlu adanya dukungan dan kerjasama baik dari pihak pendidik, peserta didik, maupun wali peserta didik agar pembelajaran jarak jauh pada pendidikan anak usia dini dapat terus berjalan dengan baik.

Dalam pembelajaran jarak jauh pemilihan metode pun harus diperhatikan secra baik-baik dan teliti guna tercapainya tujuan pembelajaran yang telah ditetapkan sebelumnya. Dalam hal ini pendidik dapat menggunakan multi metode dalam pembelajaran. Pemilihan metode ini disesuaikan dengan kebutuhan peserta didik. Dari hasil wawancara penulis mendapatkan hasil bahwa pada pemebalajaran jarak jauh Pendidikan Anak usia dini dapat mengabungkan anatara metode penugasan dan metode diskusi. Dimana kedua metode ini dinilai sangat efektif karena dapat digunakan dalam pemebelajaran jarak jauh baik pada jenjang pendidikan mana pun. Selain itu, kedua metode ini pun dapat menunjang peserta didik dalam mencapai tujuan pembelajarannya.

Hasil dari wawancara lainnya yang dapat penulis simpulkan bahwa penggunan video based learning dalam pembelajaran jarak jauh pada anak usia dini dinilai efektif karena dapat meningkatkan motivasi belajar anak. Selain itu, dengan penggunaan video based learning ini dapat mengobati perasaan anak saat pembeljaran jarak jauh yang sama sekali tidak berinteraksi langsung dengan teman-temannya. Namun perlu diingat bahwa dalam penggunaan media ini perlu bimbingan orang tua pada saat proses pembelajarannya agar pembelajaran pada anak berjalan kondusif dan terbimbing.

Penerapan video based learning pada pembelajaran anak usia dini ada baiknya apabila tidak dijadikan sebagai metode pembelajaran utama, karena masih harus diselingi oleh metode pembelajaran lainnya. Walaupun dinilai efektif video pembelajaran, tidak dapat melebihi pembelajaran tatap langsung, karena pembelajaran anak usia dini yang masih abstrak butuh bimbingan istimewa dari guru. Pembelajaran tatap langsung disekolah memungkinkan adanya sosialisasi 
dengan teman temannya yang dapat menunjang kemampuan anak dalam bersosialisasi.

\section{DAFTAR PUSTAKA}

Aidid, E. (2020). Meningkatkan Prestasi Belajar Melalui Metode Resitasi. Madiun: CV. Bayfa Cendikia Indonesia.

Ana Widyastuti, Mawati, A. T., Yuniawati, I., Simarmata, J., Fernando, A., Ardiana, P. S., . . Inayah, A. N. (2020). Pengantar Teknologi Pendidikan. (T. Limbong, Penyunt.) Medan: Yayasan Kita Menulis.

Bratanoto, V. Z., Latiana, L., \& Formen, A. (2020). Penguatan Pembelajaran Jarak Jauh Anak Usia Dini Melalui Pendekatan STEAM Dan Pemberdayaan Keluarga. In Prosiding Seminar Nasional Pascasarjana (PROSNAMPAS) (Vol. 3, No. 1, pp. 661-670).

Darmadi. (2017). Pengembangan Model dan Metode Pembelajaran dalam Dinamika Belajar Siswa. Yogyakarta: Deepublish.

Doby P, Galang P (2020). Efektivitas Media Pembelajaran Berbasis Video Pembelajaran dalam Pembelajaran Jarak Jauh. Seminar Nasional Penelitian 2020. Universitas Muhammadiah Jakarta

Dwi i, I. P. (2021). Efektivitas Media Pembelajaran Menggunkan Video Zoom Cloud Meeting pada Anak Usia Dini Era Pandemi Covid-19. Jurnal Obsesi : Jurnal Pendidikan Anak Usia Dini, 665-675.

Kemendikbud RI PAUD. 2016, 30 Maret. "Memahami Pendidikan Anak Usia Dini". Diakses April, 202i dari http://paud.kemdikbud.go.id/2016/03/30/ memahami-pendidikan-anak-usia-dini/

Maemunawati, S., \& Alif, M. (2020). Peran Guru, Orang Tua, Metode dan Media Pembelajaran: Stategi KBM di Masa Pandemi Covid-19. Serang, Banten: Penerbit 3M Media Karya Serang.

Margiani, V. (2014). Penerapan Strategi Pembelajaran Melalui Bermain Pada Anak Usia Dini Di Taman Penitipan Anak Al-Fitroh Kecamatan Tempel Kabupaten Sleman Skripsi FIP Universitas Negeri Yogyakarta. (Jalal, 1970)

Nika C, Rita K (2020). Peran Orangtua Dalam Menerapkan Pembelajaran Di Rumah Saat Pandemi Covid 19. Jurnal Golden Age, Universitas Hamzawali, 4(1), 152 - 159.

Niken S (2018).Pengaruh Pembelajaran Jarak Jauh Dengan Aplikasi Google Class
Terhadap Hasil Belajar Mahasiswa. Jurnal Pendidikan Agama Islam

Pakpahan, A. F., Ardiana, D. P., Mewati, A. T., Wagiu, E. B., Simarmata, J., Mansyur, M. D., . . . Iskandar, A. (2020). Pengembangan Media Pembelajaran. (A. Karim, \& S. Purba, Penyunt.) Medan: Yayasan Kita Menulis.

Putry, H. M. E., Nuzulul'Adila, V., Sholeha, R., \& Hilmi, D. (2020). Video Based Learning Sebagai Tren Media Pembelajaran Di Era 4.0. Tarbiyatuna: Jurnal Pendidikan Ilmiah, 5(1), 1-24.

Purwanto, A., Pramono, R., Asbari, M., Hyun, C. C., Wijayanti, L. M., \& Putri, R. S. (2020). Studi eksploratif dampak pandemi (Soares, 2013) COVID-19 terhadap proses pembelajaran online di sekolah dasar. EduPsyCouns: Journal of Education, Psychology and Counseling, 2(1), 1-12.

Pramana, C. (2020). Pembelajaran Pendidikan Anak Usia Dini (PAUD) Dimasa Pandemi Covid-19. Indonesian Journal of Early Childhood: Jurnal Dunia Anak Usia Dini, $\quad 2(2), 116-$ 124.https://doi.org/10.35473/ijec.v2i2.55 7

Rudi S, Cepi R (2011) Media Pembelajaran, Bandung: CV Wacan Prima, diterbitkan April 2011

Rusman. (2010). Model-Model Pembelajaran. Jakarta: PT. Grafindo Persada. (2018). Pendidikan, Belajar \& Pembelajaran Berorientasi Standar Proses. Jakarta: Prenadamedia Group.

Rosyada, D. (2020). Penelitian Kualitatif Untuk Ilmu Pendidikan. Jakarta: Kencana

Sarwa. (2021). Pembelajaran Jarak Jauh: Konsep, Masalah, dan Soulusi. Indramayu, Jawa Barat: Adab (CV. Adanu Abimata)

Smaldino, S. E., lowther, D. L., \& Russell, J. D. (2011). Instuctional Technology and Media for Learning: Teknologi Pembelajaran dan Media untuk Belajar. (A. Rahman, Penerj.) Jakarta: Prenadamedia Group (Divisi Kecana)

Sofyan H. (2017). Efektivitas Penggunaan Video Sebagai Media Pembelajaran Untuk Siswa Sekolah Dasar. Makalah

Sudiyono. (2020). Metode Diskusi Kelompok dan Penerapannya dalam Pembelajaran Bahasa Indonesia di SMP. Indramayu, Jawa Barat: Adab (CV. Adanu Abimata). 
Jurnal Teknologi Pendidikan, Vol. 14, No. 2, Oktober 2021, e-ISSN: 2407-7437

Srigati N. (2015). Penggunaan Multi Metode untuk Meningkatkan Motivasi dan Hasil Belajar Mata Pelajaran Matematika Pokok Bahasan Satuan Waktu Siswa Kelas I Sekolah Dasar Negeri Kandat 1. Jurnal Pinus, 1(2), 153164

Wijaya, L, D., \& Kurniawati, E. 2020, 1 Oktober. "Dampak Negatif dan Positif Pembelajaran Jarak Jauh Selama Pandemi Covid-19". Tempo.co.id Diakses April, 2021, dari

https://metro.tempo.co/read/1391861/da mpak-negatif-dan-positif-pembelajaranjarak-jauh-selama-pandemi-covid-19 